\title{
Towards Effective E-learning Through a Roadmap
}

\author{
Galal eldin Abbas Eltayeb ${ }^{1}$ \\ Computer Department, College of Science and Arts in Ar Rass, Qassim University, Kingdom of Saudi Arabia ${ }^{1}$
}

\begin{abstract}
Days going on and the concept of e-learning enlarging in its details, tools, methods within the rapid development of cyberspace and its components, including the revolution in smartphones and requests for use it in learning and education. For that and more we need to put clear milestones, that can be traced to access available knowledge about e-learning, and use it in easier ways to understand the whole idea of e-learning in its components and how to interconnect between them. To remove the ambiguity and confusion that can arise when using various methods and tools in e-learning; thus, providing many people with a sense of comfort with the difficulty details of e-learning.

This paper discusses the possibility of suggesting a roadmap that can be traced to access e-learning effectively, that by clarifying tangible foundations; which can be addressed and focus on when we want to use or design e-learning applications without going into variant ways may make it difficult. Especially in the basic concepts of e-learning and supporting infrastructure and the mechanism for the development of strategies, objectives, and tools. Taking in mind the effectiveness, assessing the quality, standards, and put all on a roadmap.
\end{abstract}

Keywords: Computer, Internet, Education, Cyberspace, E-learning, E-teaching, e-education, roadmap, authoring tools, web, www, Information technology (IT).

\section{INTRODUCTION}

It is observed on the reality of e-learning and its applications, especially in higher education, we found that the field is wide and expandable day after day through the diversity of tools, mechanisms, and technologies, that used in the educational process in the e-learning systems. The variations in procedures, approaches, and synonyms between eteaching and e-learning terms, and the fact that one of them is a part of the other or contains it. Therefore, on the spot of this great momentum; we want to suggest a roadmap; as an alphabet or a procedural guide for applying e-learning, that to facilitate its concepts and significance.

To reach the foregoing, this paper deals with the basic concepts and their applied significance and looking for tools and means to match the diversity of e-learning, with accessing educational quality processes.

\section{CONCEPTUAL FRAMEWORK}

\section{A. E-Learning}

A pattern of learning that uses electronic means and techniques to communicate the learning process, manage the interaction between teacher and student, and between students themselves, students, and learning sources, this pattern is consider an electronic attendance education. Moreover, e-learning defined as learning mediated by any electronic means [44]. In general, e-learning relies on the web to deliver educational content, where the learner and the teacher are separated from each other. In this context, we find that the goals and objectives of e-learning are concerned with applying this concept to the events involved in the educational process of a teacher; learner; educational material; and educational medium. Therefore, to adapt to these elements combined in the shadow of an electronic world, we must take into account the foundations of access to its real significance, so we reach the concept of e-learning expected through the use of the components.

The educational process does not make the electronic concept merely a template or container for preserving and exchanging educational content only; what we can call automated education, or modelling education and non-e-learning achieved the comprehensiveness of the concept of the electronic process of learning?

\section{B. E-Learning objectives}

Considering the e-learning goals that many e-learning theorists [19], we can summarize them as:

- An effective and interactive relationship between the teacher and the learner through electronic media.

- Availability and sharing of educational content anywhere, anytime.

- Flexibility in educational administrative procedures and an abundance of educational services. 


\section{E-Learning elements}

While there is no rule saying you must include specific elements and components when building e-learning materials, it is helpful for new e-learning developer to be familiar with the basic elements normally detected by the most.

Hence, through these default and expectable elements, which it should be clear in partial or total achievement as achieved steps on the thresholds of the procedures required as a specific plan for implementing the e-learning process. We counted some elements as follows:

- Welcome message.

- Instructions and terms.

- $\quad$ Learning Objectives.

- Contents and Library.

- Delivering.

- Interaction tools.

- Visualization and Multimedia.

- Activities and Assessment.

\section{E-learning strategy}

In principle, we must develop implementable strategies to help the institution focus on how to achieve its goals in the elearning environment and must be in line with e-learning needs and take into account the advice of other business owners or stakeholder engagement similar to the following strategies [38]:

- Business strategy, to achieve the objectives of the institution, and to introduce the goal, mission, and vision of the institution; and how it intends to compete with institutions with similar objectives.

- IT strategy, to accommodate appropriate technologies and show how to manage and adapt them into the educational environment rationally and economically.

- Infrastructure strategy, to achieve administrative and economic feasibility.

- Operations Strategy, to put priorities that distinguish between e-business and e-learning work.

- Human resources strategy, which determines how the institution invests in human capital and harnesses it to implement the best business strategies and achieve the desired outputs.

- Knowledge management strategy, which seeks the highest standards; so it includes experience and knowledge and transforms it into a cognitive behavior that characterizes the institution.

\section{E. E-learning institution}

It is a natural or virtual foundation, which is called a school or university, which comprises a class or classroom, lecture halls, workshops, or training field or laboratories. This institution has an administrative leadership represented by a person who assigned general manager of the administrative and educational performance of E-learning inside this institution, supported by an administrative team including employees and laborers.

Besides, everyone belongs to this institution, has the responsibility to work in the best available way, and performing all educational and supervisory work required of him, like administrative processes of registering students, follow up their financial and administrative obligations. Also, the manager should provide teachers, supervisors, and technological support for the educational program.

\section{F. E-learning course}

E-learning course or curriculum is the educational material that supposed the student to receive and which depends on computer software [34], and the contents of the course vary to ensure all educational needs of education, learning, and training, various activities and evaluation methods.

Course sources, which must use all electronic devices to exchange information and management work between the student and the institution, and include all forms of educational enrichment that activate and improve the educational process such as content management systems (CMS) and computer programs, training, simulation programs and the use of electronic communication of various types available.

\section{G. E-learning Supervisor}

In the reality of e-learning the term "Supervisor", is suitable for most of the tasks performed by the e-learning teacher in being more supervisory than educational. This supervisor expects to have some qualifications and advantages that help him perform his tasks as expected, so he is a promoter of interaction in the educational process, and motivating the learner's to generate knowledge and creativity [10], proofing that the facilitative role is greater than the teaching role in the educational process.

\section{H. E-learning Objectives Indicators}

By reviewing and studying the reality of the effectiveness of e-learning use and its applications, we take some objectives like: 
- Overcoming the limitations of space or time in the educational process.

- $\quad$ Expand access to education and overcome the obstacles of limited space.

- Enabling educational institutions to optimize the distribution of their limited resources.

- Take into account individual differences between learners and enable them to complete learning processes in environments suitable for them.

- Allow learners to interact instantly electronically between them and between them and the teacher on the other through e-mail, discussion boards, chat rooms, etc.

- Spreading a culture of self-learning and training in the community to enable the improvement and development of the abilities of learners and trainees at the lowest cost and with minimal effort.

- Raise students' sense of equality in the distribution of opportunities in the educational process, break the barrier of fear and anxiety, and enable learners to express their ideas and search for facts and information in more meaningful ways than traditional classrooms.

- $\quad$ Easy access to the teacher even outside official working hours.

- Reducing the administrative burdens of courses by using electronic means and tools in communicating information, duties, and assignments to learners and assessing their performance.

- Use different, more accurate and fair methods in evaluating the performance of learners.

- Enable the student to receive the scientific material in a manner that suits his abilities through the visual, audio, or readable method and so on.

- $\quad$ Provide a huge and renewed balance of scientific content, tests, and teaching history for each course that enables development, improvement, and increases the effectiveness of its teaching methods.

\section{The E-learning Tools}

This is the cornerstone of electronic concepts in the educational process. The concept of "instructional" tools or methods was previously resonant, has its schools and variations, and the theory of methods and their significance has expanded to fall under the concept of "Education Technology" [9]. The concept of e-learning techniques or tools are incompatible and differ with education technology in its components, and for the generality of the concept of use and purposes, e-learning tools we can classify it:

\section{J. E-learning Transformation tools}

E-learning 1.0 (Traditional Tools): It includes the tools with which education began taking advantage of the Internet access and the services available to present educational material, training, and evaluation through learning management systems (LMS) and educational sites.

E-Learning 2.0 (Modern Generation): Canadian researcher Stephen Downes [37], coined the term e-learning 2.0 as a development derived from general e-learning and combines trends in public e-learning with web 2.0 technology, which accommodates future Internet tools and applications. That allows the exchange of data and information between individuals and institutions through a range of communication, collaboration, and sharing, such as blog, Wikis, Second Life, and social networks such as Facebook, Twitter, Myspace, Hi5, LinkedIn, and linked LinkedIn.

\section{K. E-learning Delivery Platforms}

E-learning access platforms are e-learning management systems, a suite of software that complements the management of the teaching and learning activities in terms of educational programs, curricula, and courses. They involve both administrative and educational processes, which also accommodate the principle of interaction between teachers and learners and it concern with training, exercises, tests, and academic progress reports, it considered one of the most important e-learning solutions in teaching and learning institutions, especially universities. It agrees with the concepts and principles upon which they built despite some design and structural differences, like:

- Course Management Systems (CMS)

- $\quad$ Learning Management Systems (LMS).

- Learning Content Management System (LCMS).

- E-learning Platform.

- Portal of Education.

Each of these names or types includes several free, open-source or commercial products; and the educational institution can adopt from them whatever is appropriate for its activities.

\section{E-Learning Authoring Tools}

Authoring tools are those tools and programs used to create educational content in the form of electronic content displayed on the Internet, or in the form of educational discs (CDs). These tools have many advantages [20] including:

- Create web pages.

- Doing educational activities. 
- $\quad$ Creating and managing tests and exams.

- Designing displayable presentations.

- Merge/split educational content to/from each other.

- Doing or developing interactive activities that help in the communication process between the learner and the educational program.

Authoring tools are available and often uses ready-made templates to facilitate the design and authoring of educational content, such as:

- Macromedia Authorware (https://www.adobe.com/).

- CourseLab (http://www.courselab.com/).

- Learning eXe (https://exelearning.net/).

- HotPotatoes (https://hotpot.uvic.ca/).

- CyberLink Stream Author (https://www.cyberlink.com/).

On the other side simulation tools also they used to represent the content of e-learning materials, using of simulation models is not new, such it passes through animation and interactive presentations in laboratories, warehouses, and testing theories. But their use in e-learning came late; and some simulations products lays on communication and data transfer between learners and their teachers, visualization of data processes, saving the costs and complexities of the real learning environment implementation.

Among these products, we find [41]:

- DazzlerMax (https://www.maxit.com/)

- Forio Broadcast (https://forio.com/)

- $\quad$ On Demand (https://www.globalknowledge.com/)

\section{E-learning Assessment tools}

One of the important areas for the use of e-learning is the process of measuring the mental and cognitive abilities of students, and for this, the tests were an important measure to be understood and designed. The tests and self-response measures are considered one of the rich and important areas [22]. Moreover, the use of testing and evaluation methods has spread in many educational institutions, and there are many different tools, including:

- $\quad$ Short Quizzes exams.

- Essays.

- E-Portfolios (achievement files).

- Performance Evaluation.

- Interviews.

- Journals.

- Paper Work.

- Paper Reflective.

- Number of participants.

- Peer Assessment.

- Self-assessment.

- Discussion Groups

\section{N. E-learning exchange tools}

The tools of interaction and exchange are those tools that enable communication and data exchange between users in the e-learning environment. This communication can be synchronized or unsynchronized according to the available method, and e-learning institutions race in the selection of the best and most comprehensive, and allows interactive to gain a good link between the educational environment and learners. Enlarging number of learners to participate in the educational process as well as communication evaluation of the performance of learners and educational technical support, consultation and survey, this is in the processes of teaching, training, and evaluation, and among the most frequently used tools: Integrative Board, Discussion Board, Wiki, Blogs, Games, Quizzes, and Simulations.

\section{O. E-learning Social Networks}

Social networking is a service set up and programmed by large companies to collect and connect users and friends, share activities and interests, and to find friends and families, and to search for interests and activities shared by other people. Most networks are Internet sites that offer a range of services to users such as instant chat, private messaging, email, video, blogging, file sharing, and other services. Social networks have made a great change in how people and communities are involved and share information. Among the most popular social networks currently available are: Facebook, Myspace, Twitter, Live Poon, High-five, Orkut and Google+, these networks and platforms are widely used in e-learning as effective and accessible tools. 


\section{P. E-learning content Builders}

E-learning content is subject to the design and construction procedures used when building self-learning content, taking into account the legalization of procedures for an electronic environment, to exchange and manage information. Some models are presented for the design of e-learning [25] [45] [2] so that any of them can be adopted. Also, attention to the existence of the interactive environment that hoped to use and determine the contents. And how they interact, and what the interaction responses entail. As well as the global and compatible standards used in the learning environment must be taken into account when building e-learning content [17], to ensure that educational concepts and pedagogical concepts, are included and harmonized in the content. The move towards e-learning also includes the clarity of the lecture plan and modules and the identification of student groups receiving e-learning, educational process management, student calendar, reporting, and statistics. Merrinboer, et al said:

"Many e-learning applications are of low quality in the principles of teaching science, and from the perspective of teaching science, e-learning is a step backward, rather than being a step forward. The central concept is content that providers such as publishers, universities, others transmit online, teaching science is not an issue at all in that concept; instead, questions often focus on the cost and technical structure that is needed." [44].

Such statements make educational content designers peel up only in what we've previously called the automation of learning, and transform content into just electronic content; thus devoid of the concept of technology and purpose [12]. The following figure (Fig. 1) illustrates the expected relationship between elements of the educational process under elearning [1].

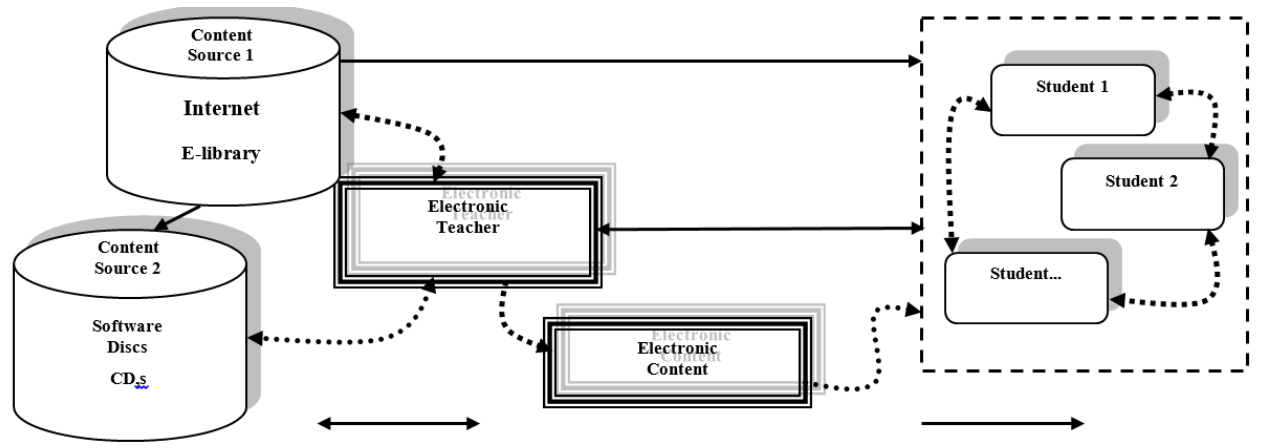

Fig. 1. The relationship between the educational process elements

\section{Q. Effectiveness of E-learning}

Many questions are raised in this regard, such as those raised by Dr. Al-Musa " Are all e-lessons effective? Are all distance learning programs using effective tools?" [3], in his answer, he pointed out that teachers and students are interested in achieving effectiveness by participating and interacting with the issues of the educational community and expressing feedback after engaging with the diversity of sources and tools of education.

Some items can lead to effectiveness include:

- Accuracy in preparing educational programs.

- Consider educational programs for the nature of the learner, his inclinations and desires.

- Choose the appropriate channel/tool/devices of communication.

- The availability of transmission and reception aids that enable the learner to interact with the educational material.

- Efficiency and cost of communication devices.

- The learner's desire, seriousness to learn, and his patience to follow up.

- The variety of enjoyments and attractions to attract the attention of the learner.

\section{R. E-learning Standardization}

Some academics believe that there are no standards for the quality of e-learning, despite the existence of reference studies in this regard, that originated and established how to control quality in e-learning such as the study of the Joint Information Systems Committee (JISC). Retrieved from http://www.jisc.ac.uk [6]. Moreover, that the quality is easy to describe than defined by some indicators describing the goal, clarity, importance, technical skills, and ease of implementation to reach the stated goals and then describing and estimating costs. Also, through this description it is easy to judge the quality of e-learning without going into definitions and standards that may not be measured and suggested from time to time, several standards for e-learning from relevant institutions such as [21] [26]:

- IMS: Instructional Management System Global (https://site.imsglobal.org/).

- IEEE: The Institute of Electrical and Electronics Engineers ( https://www.ieee.org/)

- ARIADNE: Alliance of Remote International Authoring \& Distribution Networks for Europe (https://www.ariadne-eu.org/).

- AICC: Aviation Industry CBT Committee (https://www.igi-global.com/)

- ADL: Advanced Distributed Learning Initiative (https://adlnet.gov/) 
Because of these attempts and efforts, the first standard Sharable Content Object Model (SCORM) has recently appeared in the United States of America, which is launched by (ADL), and several institutions have participated in this standard and we can conclude the following relationship in the SCORM standard:

$$
A I C C+I E E E+I M S+A D L=S C O R M
$$

SCORM supports availability, adaptability, economics, durability, Interactivity, interoperability, and reusability of the elearning. This criterion has been spreading during the past few years only, and SCORM has translated into the "reference model for the components of the publicly shared content". The SCORM standard is three different groups of metrics (specifications) collected from various educational and technological institutions, which constitute a technical reference for the development of educational digital content. These groups are, [5] [42]:

1. Content aggregation model.

2. Runtime environment.

3. Arrange and conduct.

One of the important features of the SCORM standards is that it depends on the fragmentation of the e-learning content into its original components or units and making it susceptible to sharing through aggregation and configuration, according to the requirements of the educational process. Thus, when applying the SCORM standards to build e-learning content, the following features achieved:

- The ability to publish educational digital content in any environment dedicated to managing educational content.

- Access to educational content from anywhere, anytime.

- The ability to use the content even if the technology used to display it or the operating systems it works on has changed.

- The ability to adapt to educational institutions and individuals to meet their educational needs.

- The ability to operate on different communication platforms and operating systems.

- The ability to exchange information and create an interactive and complementary learning environment.

- The ability to easily modify content and use it multiple times using multiple tools, platforms, and operating systems, and they may be different.

The following figure (Fig. 2) shows the interconnections of these standards.

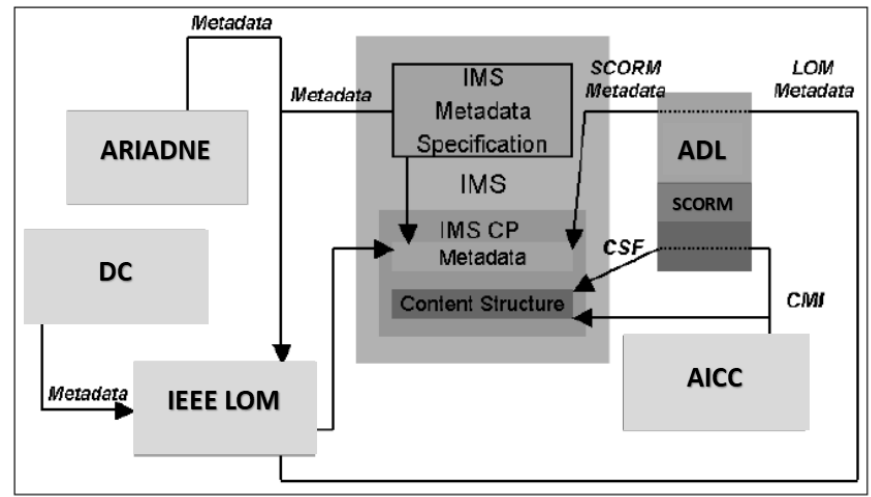

Fig. 2. The Interconnections of E-learning Standards

\section{DISCUSSION}

\section{A. Proposed Roadmap}

It is important to recognize that, according to Zainab; there are some attempts to develop a roadmap for e-learning, [45] [33], that are often interested in building a good foundation for e-learning. Dublin City University's National Center for Technology in Education (NCTE) produced a handbook called: 'Planning and Implementing e-Learning in your school' as a roadmap to guide schools to develop strategies and action plans to integrate ICT into learning and teaching across the curriculum [15]. Also, NCTE to create the tool to help e-learning institutions to determine the relationship with elearning components, and implementation of it. This tool provides several data:

- $\quad$ Leadership and planning for e-learning.

- Information and communication technology (ICT) infrastructure.

- The curricula.

- Skill development.

- $\quad$ Spreading culture of e-learning. 
Faul and Parcker indicated that the educational institutions have institutional agendas that compete with each other, which undermines attempts to develop roadmaps during the EFA era [31]. Therefore, it is not possible to ascertain the success of these proposals.

In this paper to figure out some stones on the roadmap for effective e-learning, in the matter of adding new innovative concept, some questions are raised, to define some the general parameters in that way, these questions are:

- What do we want to offer from an educational material?

- In what form do we present an educational material?

- What containers do we use, and how do we manage them?

- What do learners do with what we give them?

It is very easy to answer these questions by expressing current practices. But in this paper, we look for an applicable guide to expresses the message and tools of e-learning to wider horizons, and addresses some of the current problems facing e-learning institutions, in terms of the components and indicators mentioned before, and this guide or the roadmap can reflect the processes of learning at the following stages:

Stage 1. Select an appropriate e-learning type: Choosing e-learning type, which is supporting the institution educational process (the curricula), variating in deliver mode between full electronic, facilitating and blending, that variation can distribute and eliminate the cost, time and expanding the knowledge contents.

Stage 2. Define the management mechanism for adopting e-learning type: Attracting motivated and qualified instructors, managers, and facilitators, who can focusing on how to manage and deliver e-learning type concepts effectively.

Stage 3. Engage with the description of the courses, and identify of their resources and scientific references.

Stage 4. Determine how and when learner receives the contents: Defining the ICT equipment and the acquisition of basic ICT skills, and focusing on IT infrastructure and resources. Reporting the choices after comparing e-learning resources, technologies, and containers (CMS/ LMS / LXP / cloud-based learning management systems).

Stage 5. Determine the mechanism to assess and evaluates learner's activities: Define the assessment approaches according to the available ICT resources, and select the suitable and the best mechanism for learners to get access to the content and do their activities and get a feedback online.

Stage 6. Determine the support center and guide manual for staff and learners: Define institution contents policies and completion requirements for both staff and learners, and develop a center to support resources, strategies, and practices. Stage 7. Drafting rules, terms and copyright documents: Drafting laws and regulations; including copyright and any common notes, formulate instructions that give physical, social, emotional, and intellectual supports intended to enable all learners to have an equal opportunity to fully access their roles.

\section{B. Obstacles on the roadmap}

Legendary American professional baseball player Yogi Berra is famously quoting for saying, "If you don't know where you are going, you'll end up someplace else." [13] However, there are obstacles you may meet during the planning and performing a roadmap, which must be overcome before those processes can be achieved, these can questioning its effectiveness and limiting its complementarity and the following Table 1 puts some obstacle and how the proposed roadmap to overcome them:

Table 1. Obstacle and the Proposed Roadmap.

\begin{tabular}{|l|l|}
\hline Obstacle & Roadmap Action \\
\hline $\begin{array}{l}\text { The real cost of e-learning programs, and training for } \\
\text { teachers to deal with the e-learning techniques and } \\
\text { how to interact with them [36]. }\end{array}$ & $\begin{array}{l}\text { Develop an economical mechanism for developing e- } \\
\text { learning programs do not start from scratch (zero), but it is } \\
\text { necessary to fit with the type you suggest including the } \\
\text { quantity and ethics of the educational institution. }\end{array}$ \\
\hline $\begin{array}{l}\text { The loss of interactive and dynamic educational } \\
\text { websites capable of occupying and encouraging the } \\
\text { learner, due to the difficulty of creating an } \\
\text { interactive environment using traditional educational } \\
\text { programming tools that may require the addition of } \\
\text { multimedia components. [29]. }\end{array}$ & $\begin{array}{l}\text { Design an Internal training programs for the technical } \\
\text { team specialized in the development and programming of } \\
\text { the educational material requirements. }\end{array}$ \\
\hline $\begin{array}{l}\text { Gaps in the concept of virtual teacher, a teacher who } \\
\text { interacts with the learner electronically and is } \\
\text { responsible for educational supervision [10 ]. }\end{array}$ & $\begin{array}{l}\text { Good training is required for e-learning supervisors, } \\
\text { including all the possibilities of electronic communication } \\
\text { and educational content design and management systems, } \\
\text { as well as assessing methods and systems. }\end{array}$ \\
\hline
\end{tabular}




\section{Proposed Roadmap Diagram}

As shown in Fig. 5. We will draw this map to show needed stages and their connections:

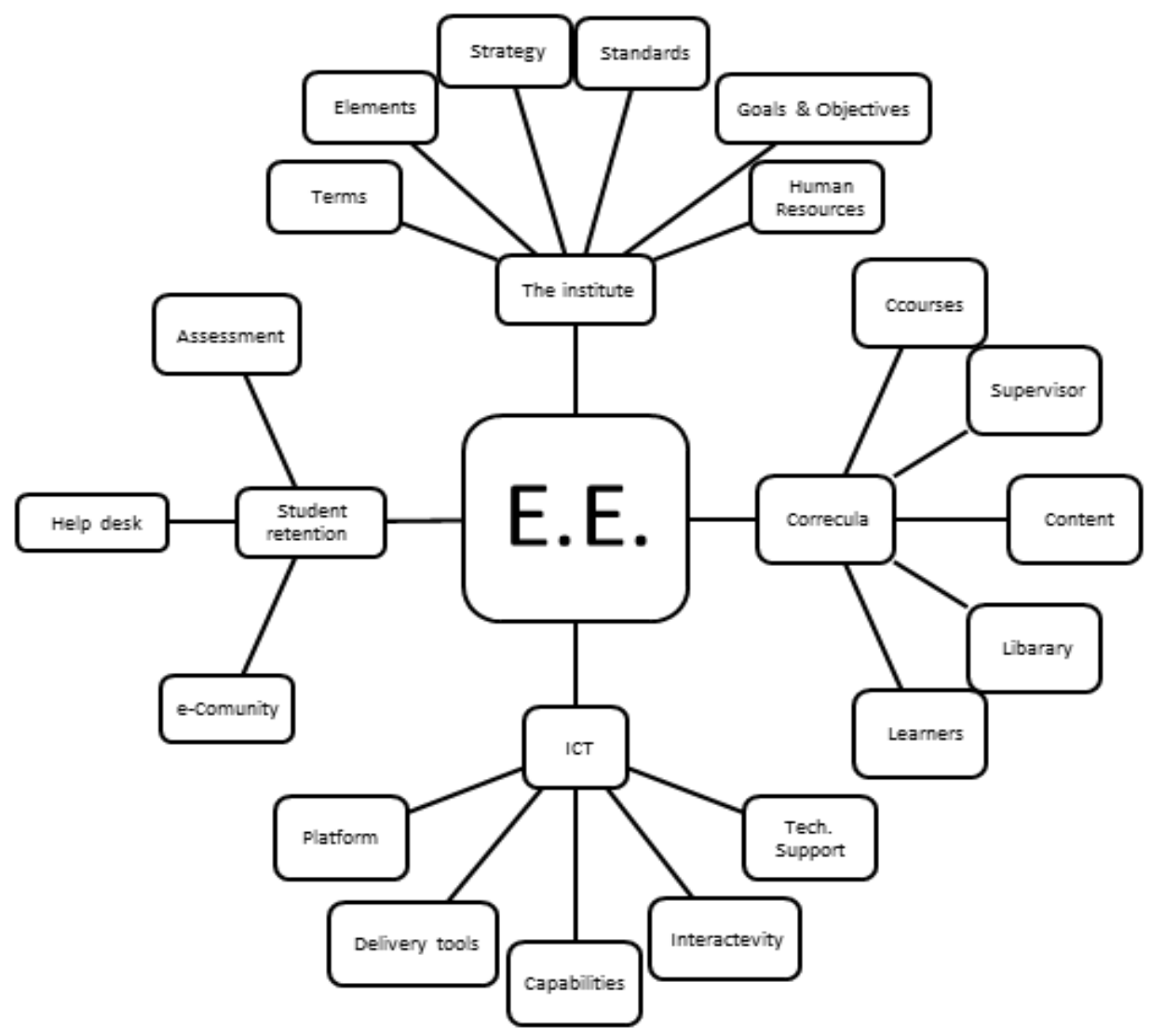

Fig. 5. The stages map and their connections

\section{CONCLUSION}

This paper concludes that the pursuit to access effective e-learning needs careful consideration of the proposed steps on a roadmap, through which it is necessary to clearly define the ultimate goal and the staged objectives of the e-learning process, including humans, technologies and administrative. Considerations, which requires a study of the urgent strategies that must develop a framework for the educational needs, guided in accomplishing tasks and achieving goals as well as working to achieve the best option in the design of educational programs and the use of new techniques, computer software and methods of follow-up. Also, training, assessing, and handling. That to attract qualified e-learning supervisors who are highly trained and motivated and thus to expose effective processes, requirements, and techniques to serve the best education institution choices for effective e-learning. Hence when we follow the proposed stages as shown in this work, and connections in Fig. 5, we try to add applicable steps to lead to effective e-learning.

\section{REFERENCES}

[1]. A. A. Al-Baladawi, and R. A. Hassan, (2010, April), "Theoretical and applied frameworks for the use of e-courses in the educational process," The Role of E-Learning Conference in The Promotion of Knowledge Societies, Zain E-Learning Center, University of Bahrain.

[2]. A. A. Al-Ganzuri, (2005), "The effectiveness of an interactive multimedia program in achieving the goals of the computer curriculum for middle school students," unpublished master's thesis, Faculty of Quality Education, Ain Shams University.

[3]. A. A. Al-Musa, (2002), "E-learning is understood. Properties... His benefits. 'Obstacles'," a working paper presented to the Future School Symposium on 16-17/8/1423 H. King Saud University.

[4]. A. A. Alqarni (2015, October), "EDUCATIONAL TECHNOLOGY IN SAUDI ARABIA: A HISTORICAL OVERVIEW," International Journal of Education, Learning and Development Vol.3, No.8, pp.62-69.

[5]. A. Bakhouyi, R. Dehbi, M. Talea, and O. Hajoui, (2017), "Evolution of standardization and interoperability on E-learning systems: An overview," 1-8. 10.1109 / ITHET .2017. 8067789.

[6]. A. Bakr, (2000), "Readings in Distance Education," Dar Al Wafa for the World of Printing and Publishing, Alexandria, Egypt.

[7]. A. Elmabaredy, and E. El-Kholy, (2020), "Skills of Employing Mobile Learning Applications Required for Faculty of Education Students in Light of their Training Needs3," 227-272. 10.29009/ijres.3.1.5.

[8]. A. K. Mohamed, (2015, April), "Adaptive e-Learning Environment Systems and Technologies," The First International Conference of the Faculty of Education, "Education .... Future Prospectives", Albaha University, during the period 13-15 / 4/2015. 


\title{
International Journal of Advanced Research in Computer and Communication Engineering
}

\author{
Vol. 9, Issue 6, June 2020
}

[9]. A. M. Kadok, (2000), Education technology (what, the foundations, and practical applications). First edition, Riyadh: Vocabulary House for Publishing and Distribution

[10]. A. N. Darwazeh, (1999, April 10), "The Role of the Teacher in the Internet Age," Conference on Distance Learning and the Role of Technology and Information, April 10-12, 1999 Amman, Jordan.

[11]. ADL: Advanced Distributed Learning Collaborators, (2015, Sep 25), "Choosing a Learning Management System Advanced", Version 4.10.

[12]. B. Al-Saleh, (2005), "E-learning and educational design: Partnership for Quality," 10th Scientific Conference of the Egyptian Society for Education Technology, Cairo.

[13]. B. Yogi (2020, April 23), Quotes. Retrieved from https://yogiberramuseum.org/

[14]. C. C. Chang, (2015), "Alteration of Influencing Factors of Continued Intentions to Use e-Learning for Different Degrees of Adult Online Participation." The International Review of Research in Open and Distributed Learning, 16(4). https://doi.org/10.19173/irrodl.v16i4.2084

[15]. C. Saul, and S. Patti, (2010, March), The E-Learning Handbook: Past Promises, Present Challenges). ISBN-13: 978-0787978310. ISBN-10: 0787978310. eLearn . Print

[16]. D. Vlachopoulos, (2016), "Assuring Quality in E-Learning Course Design: The Roadmap," The International Review of Research in Open and Distributed Learning, 17(6). https://doi.org/10.19173/irrodl.v17i6.2784

[17]. E. M. Fodah, (2002), Computers and its use in Education. Second edition, Riyadh, Greer Library, Obeikan, 2002. ISBN978-603-068-2.

[18]. E. Mnkandla, and A. Minnaar, (2017), "The Use of Social Media in E-Learning: A Metasynthesis," The International Review of Research in Open and Distributed Learning, 18(5). https://doi.org/10.19173/irrodl.v18i5.3014

[19]. F. Alonso, J. Couchet, D. Manrique, and F. Soriano, (2006), "Learning Objectives for E-Learning Instruction."

[20]. G. A. Eltayeb, (2010), "Application and Evaluation of E-learning in distance learning using The Moodle Environment," Unpublished Ph.D., Nilein University, Khartoum.

[21]. G. A. Eltayeb, (2020), "The Reality of Using E-Learning Applications and the Readiness of Faculty Members: A Case Study," International Journal of Advanced Research in Computer Science, 11(3), 37-41. doi:10.26483/ijarcs.v11i3.6621

[22]. H. A. Abdul Aziz, (2008), "E-learning, philosophy, principles, tools, applications", Oman, Dar al-Fikr.

[23]. H. Al-Bitar, and M. Al-Skeef, (2003), "Prospects for e-learning and distance learning," Dar Al-Rida and Publishing, Damascus, Syria.

[24]. J. Y.Ahn and A. Edwin, (2018), "An e-Learning Model for Teaching Mathematics on an Open Source Learning Platform," The International Review of Research in Open and Distributed Learning, 19(5). https://doi.org/10.19173/irrodl.v19i5.3733

[25]. K. M. Nofal, (2004), "The impact of the interaction between learner control in the multimedia educational program and cognitive method on student achievement," Unpublished master's thesis, Faculty of Quality Education, Ain Shams University.

[26]. M. Abdullah, and N. Abdel, (2016), "E-learning standards", 10.1201 / 9781315375083-92.

[27]. M. E. Hazem and A. S. Ahmed (2013, December), "Adaptive E-Learning Based on Learner's tyles. Buletin Teknik Elektro dan Informatika," (Bulletin of Electrical Engineering and Informatics), Vol. 2, No. 4, pp. 240 251, ISSN: 2089-319.

[28]. M. H. Hur, and Y. Im, (2013), "The influence of e-learning on individual and collective empowerment in the public sector: An empirical study of Korean government employees," The International Review of Research in Open and Distributed Learning, 14(4). https://doi.org/10.19173/irrodl.v14i4.1498

[29]. M. Paris, (2003), Simulation authoring tools for interactive e-learning courseware development.

[30]. M. Raspopovic, S. Cvetanovic, and A. Jankulovic, (2016), "Challenges of Transitioning to e-learning System with Learning Objects Capabilities," The International Review of Research in Open and Distributed Learning, 17(1). https://doi.org/10.19173/irrodl.v17i1.2172

[31]. M. V. Faul, and S. Packer, (2015), "The Role of global EFA architectures," UNESCO, Education for All Global Monitoring Report 2015. ED/EFA/MRT/2015/PI/33. P47.

[32]. N. Al-Shahrani, (2009), "Demands for the use of e-learning in the teaching of natural sciences in higher education," Ph.D. in Curriculum and Teaching Methods, Faculty of Education, Um al-Qura University.

[33]. NCTE. (2020, April 23). E-learning roadmap at the National Center for Technology in Education, Dublin City University, USA. Retrieved from

[34]. R. Al-Jarf, (2001), "Electronic course," 13th Scientific Conference of the Egyptian Society for Curriculum and Teaching Methods.

[35]. R. Sivakami, and G. Poorani, (2015), "SCORM/AICC Compliance in Learning Management System and e-Learning: A Survey," International Journal of Engineering \& Computer Science ISSN:2319- 7242 Volume 4 Issue 6 June 2015, Page No. 12894-12897.

[36]. S. Al-Orini (2009), "A proposed model of distance learning in Saudi Arabia in light of the experience of the British Open University," the Malaysian Open University, \& the Arab Open University, the first international conference on e-learning, e-learning, \& distance learning, Riyadh.

[37]. S. Downes, (2005), "E-Learning 2.0," eLearn Magazine (C - Publications in Trade Journals (invited article)) Association for Computing Machinery, New York, USA, October 16, 2005.

[38]. S. Guri-Rosenblit, (2018), "E-Teaching in Higher Education: An Essential Prerequisite for E-Learning," Journal of New Approaches in Educational Research. 7. 93-97. 10.7821/naer.2018.7.298.

[39]. S. Ibrahem, (2012), "The impact of using multimedia on students' academic achievement in the College of Education at King Saud University," Journal of King Saud University - Languages and Translation. 24. 75-82. 10.1016/j.jksult.2012.05.002.

[40]. S. Jai (2018), EmergingTechnologies10-31-06 March 23, 2018. Brandon Hall Research.

[41]. S. W. Paris, and D. E. Long, (1998), "A low bandwidth broadcasting protocol for video on demand," Proceedings 7th International Conference on Computer Communications and Networks (Cat. No.98EX226). Lafayette, LA, USA. pp. 690-697.

[42]. SCORM. (2020, April 12), Advanced Distributed Learning (ADL) Initiative. Sharable Content Object Reference Model (SCORM). Since 2001. https://scorm.com/

[43]. V. Salyers, L. Carter, A. Carter, S. Myers, and P. Barrett, (2014), "The search for meaningful e-learning at Canadian universities: A multiinstitutional research study," The International Review of Research in Open and Distributed Learning, 15(6). https://doi.org/10.19173/irrodl.v15i6.1713

[44]. W. Jochems, M. Van, J. G. Jeroen, \& R. Koper, (2004), "Integrated E-Learning: Implications for Pedagogy, Technology, and Organization," $10.2307 / 1602168$.

[45]. Z. M. Amin, (2000), "Problems about education technology," Minya, Al Huda Publishing and Distribution House, i1. 